$\begin{array}{rrrr}\text { Berechnet f. }\left(\mathrm{CH}_{3} \mathrm{~S}\right)_{2} \dot{\mathrm{Hg}} & 8.15 & 2.05 & 68.05 \\ \left(\mathrm{C}_{2} \mathrm{H}_{5} \mathrm{~S}\right)_{2} \mathrm{Hg} & 14.88 & 3.12 & 62.14 \\ \left(\mathrm{C}_{3} \mathrm{H}_{7} \mathrm{~S}\right)_{2} \mathrm{Hg} & 20.53 & 4.02 & 57.17\end{array}$

Also stimmt die Analysenzahl mit der des Quecksilbermethylmercaptans überein.

Das Vorkommen von Methylmercaptan in frischer Raphanuswurzel ist liermit sicher festgestellt. Ob ein Teil desselben während der Destillation aus labiler Muttersubstanz gebildet wird, bleibt noch zu entscheiden. Es ist aber kaum zu bezweifeln, dass ein grosser Teil desselben in freiem zustande vorkommt. Aus 40 Kilo frischer Wurzeln wurden 3g. Rohquecksilberverbindungen und hieraus 1g. reines Quecksilbermethylmercaptan isoliert. Auf freies Mercaptan berechnet, entspräche es $0.32 \mathrm{~g}$.

\title{
On the Buck Wheat Protein (Fagopyrum esculentum Moench.) and its Nutritive Value.
}

\section{Minoru HARA.}

(In the Labolatory of the Nutrition Institute, Tokyo, Japan.)

(Received May 10th, 1925)

The three different samples of carefully prepared Japanese buck wheat flour were analyzed into their general constituents as follows:

Sample no. I

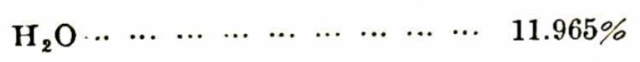

Drymatter

Drymatter\%

Cr. $\operatorname{protein}(\mathrm{N} \times 6.25) \cdots \cdots$

Protein ( $\quad \prime \quad) \quad \cdots \cdots \cdots$

$\begin{array}{llllllllll}\text { Cr. fat } & \ldots & \ldots & \ldots & \ldots & \ldots & \ldots & \ldots & \ldots & 2.964\end{array}$

$\begin{array}{llllllllll}\text { Cr. ash } & \ldots & \ldots & \ldots & \ldots & \ldots & \ldots & \ldots & \ldots & 2.276\end{array}$

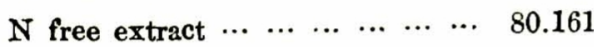

$\begin{array}{lllllllll}\text { Cr. fibre } \cdots & \ldots & \ldots & \ldots & \ldots & \ldots & \ldots & \ldots & 1.003\end{array}$

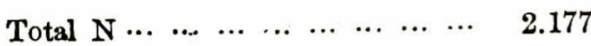

$\begin{array}{llllllllll}\text { Alb. } \mathrm{N} & \ldots & \ldots & \ldots & \ldots & \ldots & \ldots & \ldots & \ldots & 1.640\end{array}$

$\begin{array}{lllllllll}\text { Non alb. } \mathrm{N} & \ldots & \ldots & \ldots & \ldots & \ldots & \ldots & \ldots & 0.537\end{array}$
II

$12.432 \%$

87.568

13.337

10.019

2.889

2.278

80.515

0.981

2.134

1.603

0.531
III

$12.645 \%$

87.355

14.250

9.381

2.986

2.623

78.934

1.207

2.280

1.549

0.731

In showing the characters of the buck wheat nitrogenous substances on the basis of solubility under different conditions, there are two processes; one is a fractional extraction method of protein and the another an individual extraction method. 
The procedure of the former is as follows: $-20 \mathrm{~g}$. of the flour is extracted in 500c.c. aqueous solution under agitation for 6 hours at room temperature and after being filtered, 300c.c. of water is added again to the residual, repeating agitation and filtration, then all filtrates are made up to $1 \mathrm{I}$, and estimated nitrogen content by Kjeldahl's method; $10 \%$ saline solution is secondarily added to the previons residue and treated in the same manner as stated above, at last time $0.2 \% \mathrm{NaOH}$ solutiou is pursued in the same way, nitrogens estimated in each portion are as follows:

Sample no. I

\begin{tabular}{|c|c|c|}
\hline $\begin{array}{lllllllllll}\text { Water soluble } & \mathrm{N} & \ldots & \ldots & \ldots & \ldots & \ldots & \ldots & \ldots & \ldots\end{array}$ & $30.75 \%$ & $40.63 \%$ \\
\hline $10 ; \vdots \quad \mathrm{NaCl}$ soluble $\mathrm{N} \cdots\left(\begin{array}{lllllll}\cdots & \ldots & \ldots & \ldots & \ldots & \ldots & \ldots\end{array}\right.$ & 5.35 & 4.61 \\
\hline 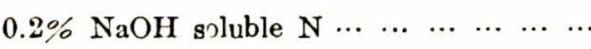 & 45.40 & 40.27 \\
\hline $\mathrm{N}$ reinained in residue & 18.50 & 14.48 \\
\hline $\begin{array}{lllllllllll}\operatorname{Total} & \mathrm{N} & \ldots & \ldots & \ldots & \ldots & \ldots & \ldots & \ldots & \ldots & \ldots\end{array}$ & 100.00 & 100.00 \\
\hline
\end{tabular}

III

$0.63 \%$

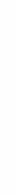

The procedure of the latter consists in extracting samples with aqueous solution, $10 \%$ saline solution, $0.2 \%$ alkaline solution and $70 \%$ alcohol solution separately. Especially in the case of alcohol extraction, temperature is constantly kept at 60$70^{\circ} \mathrm{C}$, filtration and estimation is carried out principally following the former process. The results of nitrogen determination is given as follows:

\begin{tabular}{|c|c|c|c|}
\hline & Sample no. I & II & III \\
\hline Water soluble $\mathrm{N} \ldots \ldots \ldots$ & $\begin{array}{lllllll}\cdots & \cdots & \cdots & \cdots & \cdots & 28.72 \%\end{array}$ & $21.27 \%$ & $39.63 \%$ \\
\hline $10 \% \mathrm{NaCl}$ soluble $\mathrm{N} \quad \ldots$ & $\begin{array}{llllll}\cdots & \cdots & \cdots & \cdots & \cdots\end{array}$ & 38.99 & 43.39 \\
\hline $0.2 \% \mathrm{NaOH}$ soluble $\mathrm{N}$ & $\begin{array}{lllllll}\ldots & \ldots & \ldots & \ldots & \ldots & 81.89\end{array}$ & 78.81 & 61.53 \\
\hline $70 \%$ alcohol soluble $\mathrm{N}$ & $\begin{array}{lllll}\cdots & \cdots & \cdots & \cdots & \cdots\end{array}$ & 2.52 & 2.72 \\
\hline $\begin{array}{llllll}\text { Total } & \mathrm{N} & \ldots & \ldots & \ldots & \ldots\end{array}$ & 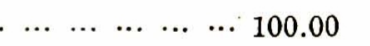 & 100.00 & 100.00 \\
\hline
\end{tabular}

Above data show that alkaline solution could extract a main bulk of nitrogen from the flour but alcohol solution only a small quantity.

Properties of the extractions :

Solutions extracted by those solvents except alcohol give all protein colour reactions and have more or less viscous character, particularly being conspicuous in the case of alkaline solution which could not be easily filtered out in the clear state.

From the water extraction the coagurable protein is separated by heating at $60-70^{\circ} \mathrm{C}$ and adding dilute acetic acid and the protein thus obtained yielded as follows: Sample no. I

Airdrymatter obtained from original flour $100 \mathrm{~g} . \quad \cdots \quad \cdots \quad \cdots \quad \cdots \quad 3.35 \mathrm{~g}$.

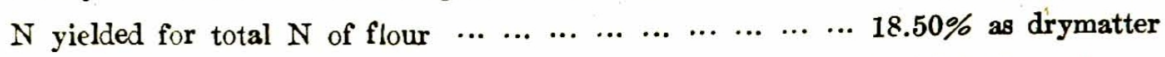

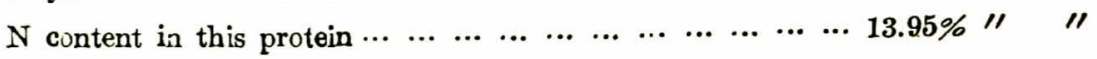


From the extraction of saline solution, globuline is separated by ordinary method of saturating with ammonium sulphate and is shown as follows:

Sample no. I

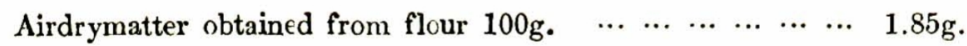

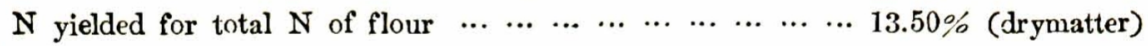

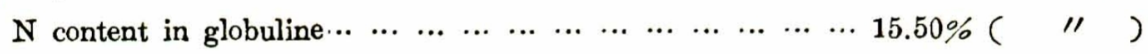

The aqueous alkali soluble protein is treated out of extraction obtaided by afore mentioned procedure as follows :- from extracted solution, protein substance is precipitated by adding acetic acid drop by drop as far as solution becomes faintly acid. This precipitate is filtered and redissolved in alkaline solution, and after repeating precipitation and filtration the precipitate is washed by water, alcolol and ether, and dried. 'This crude protein is a dark brown substance and may be considered to contain glutelin chiefly and is to be albumin and globrlin partly; but due to the difflculties of purification of individual simple protein, it is not easy to decide how much the latter two would or would not be actually involved in this substance.

Cotents of water, ash and nitrogen and yield of this suhstance are as follows:

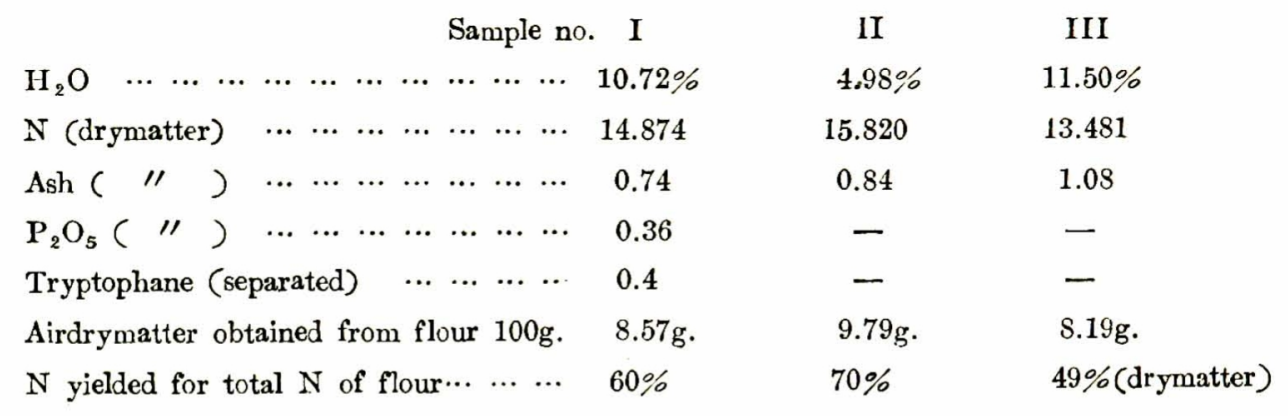

Nitrogen distribution of several groups of aminoacids is determined from this substance by Van Slyke's method as follows:

\begin{tabular}{|c|c|c|c|c|}
\hline & $\begin{array}{l}\text { Sample no. I } \\
\text { drymatter }(\%)\end{array}$ & total $N(\%)$ & $\begin{array}{c}\text { II } \\
\text { drymatter }(\%)\end{array}$ & total $N(\%)$ \\
\hline Total $N \cdots \cdots$ & $\begin{array}{lllll}. . & \ldots & \ldots & 14.892\end{array}$ & 100.00 & 15.820 & 100.00 \\
\hline $20 \%$ HCl sol. $\mathrm{N} \ldots$. & $\begin{array}{lllll}\cdots & \cdots & \cdots & 14.352\end{array}$ & 93.37 & 14.958 & 94.55 \\
\hline$" \prime \prime$ insol. $\mathrm{N}$ & $\begin{array}{llll}\ldots & \cdots & \cdots & 0.526\end{array}$ & 3.53 & 0.843 & 5.33 \\
\hline Fumin $\mathrm{N} \quad \ldots \ldots$ & $\begin{array}{llll}\cdots & \cdots & \cdots & 0.151\end{array}$ & 1.01 & 0.187 & 1.18 \\
\hline 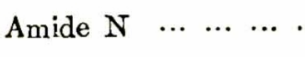 & $\begin{array}{llll}\cdots & \cdots & \cdots & 1.679\end{array}$ & 11.28 & 1.167 & 7.38 \\
\hline Phosphotungstates $\mathrm{N}$. & $\begin{array}{llll}\cdots & \cdots & \cdots & 4.586\end{array}$ & 30.80 & 4.654 & 29.42 \\
\hline Arginine $N \quad \ldots l l$. & $\begin{array}{lllll}\cdots & \cdots & \cdots & 2.247\end{array}$ & 15.09 & 2.228 & 14.08 \\
\hline 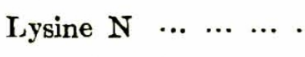 & $\begin{array}{llll}\cdots & \cdots & \cdots & 0.732\end{array}$ & 4.92 & 0.830 & 5.26 \\
\hline Histidine $\mathrm{N} \quad \ldots \quad \ldots$. & $\begin{array}{llll}\cdots & \cdots & \cdots & 1.416\end{array}$ & 9.51 & 1.371 & 8.67 \\
\hline
\end{tabular}




\begin{tabular}{|c|c|c|c|}
\hline $\begin{array}{lllllll}\text { Cystine } & \mathrm{N} & \ldots & \ldots & \ldots & \ldots & \ldots\end{array}$ & 0.191 & 1.12 & 0.225 \\
\hline $\begin{array}{llllllll}\operatorname{Amino} & N & \ldots & \ldots & \ldots & \ldots & \ldots & \ldots\end{array}$ & 1.957 & 13.14 & 2.070 \\
\hline $\begin{array}{lllllll}\text { Nonamino } & \mathrm{N} & \ldots & \ldots & \ldots & \ldots & \ldots\end{array}$ & 2.629 & 17.66 & 2.584 \\
\hline 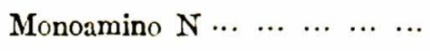 & 7.936 & 53.29 & 8.950 \\
\hline
\end{tabular}

Investigation of nutritive value of protein.

For experiments aqueous alkali soluble protein is served as protein source, on account of its comparatively large yield, and casesn is used as contrast.

Animals-Albino rat. 4 (令) and 4 (우).

Rations_-Ratio of food mixtures as follows:

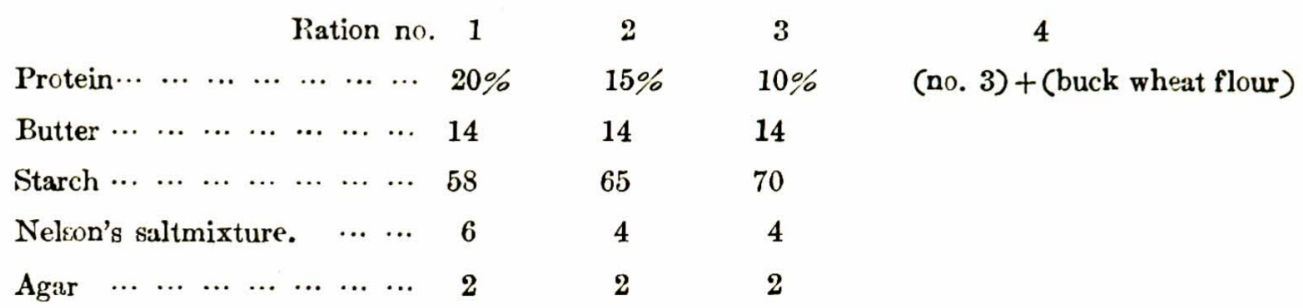

N. B. Vitamin A, B and C are supplied from butter, oryzanin and cabbage with this ration. Periods-From March 20 to Dec. 14.1924 (239 days totally).

\section{Summary :-}

1. Buck wheat flour 'contains a large portion of aqueous alkali soluble protein and small amount of coagurable protein and globulin, but none of alcohol soluble protein. All the extractive solution except that of alcohol show viscous character.

2. Aqueous alkali soluble protein contains a large quantity of arginine and histidine.

3. Inspite of the denatured protein the aqueous alkali soluble protein can be regarded, to be a fairly preferable nutritive material better than casein as vegetable protein. 